\title{
Packed cell volume and serum iron in subjects with HIV-malaria co-infection in Nnewi, South-Eastern Nigeria
}

\author{
N.R. UKIBE ${ }^{1 *}$, C.C. ONYENEKWE ${ }^{2}$, J.I. AHANEKU ${ }^{3}$, S.C. MELUDU ${ }^{1}$, S.N. UKIBE ${ }^{4}$, \\ A. ILIKA ${ }^{5}$, M. IFEANYI ${ }^{6}$, A.O. IGWEGBE ${ }^{7}$, M. EZEANI ${ }^{6}$, A. ONOCHIE ${ }^{8}$ and \\ N. OFIAELI ${ }^{9}$ \\ ${ }^{1}$ Department of Human Biochemistry, College of Health Sciences, Nnamdi Azikiwe University, Nnewi Campus, \\ PMB 5001 Nnewi, Anambra State, Nigeria. \\ ${ }^{2}$ Deparment of Medical Laboratory Science, College of Health Sciences, Nnamdi Azikiwe University, Nnewi \\ Campus, PMB 5001 Nnewi, Anambra State, Nigeria. \\ ${ }^{3}$ Department of Chemical pathology, College of Health Sciences, Nnamdi Azikiwe University, Nnewi Campus, \\ PMB 5001 Nnewi, Anambra State, Nigeria. \\ ${ }^{4}$ Department of Prosthesis and Orthopedic Technology School of Health Technology, Federal University of \\ Technology PMB 1526 Owerri \\ ${ }^{5}$ Department of community medicine, College of Health Sciences, Nnamdi Azikiwe University, Nnewi Campus, \\ PMB 5001 Nnewi, Anambra State, Nigeria. \\ ${ }^{6}$ Department of immunology, College of Health Sciences, Nnamdi Azikiwe University, Nnewi Campus, PMB \\ 5001 Nnewi, Anambra State, Nigeria. \\ ${ }^{7}$ Department of Obstetric and Gynecology, College of Health Sciences, Nnamdi Azikiwe University, Nnewi \\ Campus, PMB 5001 Nnewi, Anambra State, Nigeria. \\ ${ }^{9}$ VCT Unit, Nnamdi Azikiwe University Teaching Hospital, Nnewi, Anambra State, Nigeria. \\ ${ }^{8}$ Department of Biochemistry, Anambra State University of Science and Technology, Uli, Anambra State, \\ Nigeria. \\ *Corresponding author, E-mail: ezinne4real2007@yahoo.com
}

\begin{abstract}
The present study was designed to assess the PCV and serum iron in HIV-malaria co-infected subjects in Nnewi, South Eastern Nigeria. 207 participants aged between 16-72 (44 \pm 28$)$ years were recruited and classified as follows based on standard screening and WHO criteria: (i) Asymptomatic HIV stage I subjects with or without malaria. (ii) Symptomatic HIV stage II subjects with or without malaria and not on (ART). (iii) HIV/AIDS subjects with or without malaria and on ART. (vi) HIV seronegative control subjects with or without malaria. Blood sample from these participants were analyzed for HIV seroreactivity, Plasmodium falciparum antigen, parasite density, serum iron concentrations and PCV using Standard Laboratory methods. The result showed that serum iron and PCV were significantly reduced amongst all the groups studied when compared with the control $(\mathrm{p}<0.01,<0.05,<0.01)$ respectively. No significant difference was observed in malaria parasite densities amongst all the groups studied. The present study shows that serum iron could possibly be one of the most significant predictors of anaemia in subjects presenting with HIV-malaria coinfection, other factors not withstanding. Effective antimalarial drugs in conjunction with antiretroviral therapy could go a long-way in reducing the incidence of anaemia associated with HIV/Malaria co-infection (C) 2010 International Formulae Group. All rights reserved.
\end{abstract}

Keywords: HIV, Malaria, Serum iron, PCV. 


\section{INTRODUCTION}

The emergence of HIV infection in the early eighties has complicated the problem of malaria in endemic areas. The interaction between malaria and HIV infection has been controversial (Whitworth et al., 2005) though it has been established that the two diseases potentiate each other with greater risks of complications (Froebel et al., 2004; Xiao et al; 1998; Kublin et al., 2005; Tkachuk et al., 2001; Mermin et al., 2006; Te Kuile et al., 2004) The most notorious complication of malaria is anaemia (Mendez et al., 2004; Eliades et al., 2004; Okwa et al., 2004) Malaria causes anaemia by increased destruction of parasitized red blood cells by the reticuloendothtial system. The iron produced as a bye product of erythrocytes destruction is essentially lost and this increases the chances of iron deficiency anaemia especially when the rate of red blood cell destruction exceeds the rate of bone marrow formation of new ones.

Studies conducted in malaria endemic areas have shown that HIV infection increases the rate of clinical malaria with greater risks of anaemia (low PCV) and derangement in serum iron concentration. (Whithwort et al., 2000; Luafer et al., 2006; Patnaik et al., 2005) HIV infection can also induce anaemia by bone marrow suppression either as a result of the virus itself or due to the effects of the anti retroviral drugs used to treat the illness. A study from Italy suggests that intestinal malabsorption of iron is common among anemic HIV-infected subjects (Calstaldo et al., 1996). Loss of appetite due to advanced HIV infection or severe malaria can also lead to iron deficiency state and anaemia.

The public health importance of HIVmalaria co-infection cannot be over emphasized, especially in sub-Saharan Africa where it is estimated that 38 million people are infected with HIV-1 virus (UNAIDS 2004) whereas 300-500 million people are estimated to suffer from malaria each year (WHO 2006)

The essence of the present study is therefore to highlight the significance of the co-morbidity of malaria and HIV virus in an endemic area with stable malaria transmission, where high morbidity is attributable to anaemia especially among children and pregnant mothers (Okwa et al., 2004; Eliades et al., 2004) other indices of anaemia not withstanding.

\section{MATERIALS AND METHODS \\ Subjects}

A total of $207($ male $=100$, female $=107)$ subjects aged between 16-72 $(44 \pm 28)$ years randomly recruited at the VCT and HIV clinic in NAUTH Nnewi participated in the study. Blood samples were collected from all the participants and whole blood were used for double screening for HIV seroreactivity, $P$. falciparum malaria antigen seroreactivity, PCV, serum Iron concentration and thick and thin blood smears. Based on the result of the malaria parasite screening and WHO staging for HIV, the participants were grouped into:

(i) Asymptomatic HIV stage 1 subjects $(n=67)$ thirty-five of the participants had $P$. falciparium malaria. They have not been placed on antiretroviral therapy (ART).

(ii) Symptomatic HIV stage 11 subjects $(n=53) .28$ of these participants had malaria. They have not been placed on ART.

(iii) HIV/AIDS subjects $(\mathrm{n}=47)$ on ART. 28 of these participants had $P$. falciparum malaria parasite infection. The antiretroviral combinations used included zidovudine (ZDV) or Azithrothymidine (AZT), Lamivudine (ZTC Epivir), Stavudine (d4T, Zerit) and Nevirapine (NVP, viramine) all in standard dosages.

(iv) HIV seronegative subjects $(n=40)$. They served as control subjects. 20 of the participants had $P$. falciparum malaria.

The Ethical Committee of Nnamdi Azikiwe University Teaching Hospital Nnewi approved the study design and the participants gave informed consent.

\section{Methods}

Detection of antibodies to HIV-1 and HIV-2 in human plasma: 
Abbott Determine ${ }^{\mathrm{TM}}$ HIV 1 \& 2 method: It is a visually, read immunoassay (Abbott Japan C Ltd. Tokyo, Japan). The procedure as described by the manufacturer was used for the analysis. Briefly, 50 $\mu$ l of participants' plasma samples separated from corresponding whole blood samples in EDTA were applied to appropriately labeled sample pad. After 15 minutes of sample application, the result was read. This method has inherent quality control that validates the results. HIV seropositive results using this confirmatory test method were used to classify participants as presenting with HIV infection.

\section{Diagnosis of $\boldsymbol{P}$. falciparum malaria}

Whole Blood was used for the diagnosis of $P$. falciparum malaria using Malaria Plasmodium falciparum Rapid Test Device (Para check, Orchid Biomedical systems, Vena Goa, India) and Giemsa stained thick blood smears for microscopic detection of $P$. falciparum parasites. The parasites density was determined as previously reported (Onyenekwe et al., 2002) and density expressed per liter of blood. However, the principle of the $P$. falciparum antigen detection is based on a rapid chromatographic immunoassay for the qualitative detection of circulating $P$. falciparum antigen in the whole blood. This method makes use of Gold conjugate to selectively detect Plasmodium antigen. The procedure was as described by the manufacturer. Briefly, $10 \mu$ of the whole blood specimen from the participant were transferred into appropriately labeled specimen cassettes containing sample wells. Subsequently, 3 drops of buffer supplied by the manufacturer approximately $120 \mu \mathrm{l}$ was added into the sample wells. After 15 minutes the results were read.

\section{Determination of the Packed Cell Volume} Anti-co-angulated (EDTA) blood sample from each participant was aspirated into micro-haematocrit capillary tubes. One end of the capillary tube was subsequently sealed and placed in the micro-haematocrit centrifuge. A constant packing of the red blood cells was achieved with a centrifugation speed of $1200 \mathrm{x} \mathrm{g}$ for $3 \mathrm{~min}$. the PCV was measured and reported as a ratio of the whole blood volume in litre/litre.

\section{Serum iron determination by colorimetric method}

The procedure was as described by the manufacturer of the kit (Chromatest, Barcelona, Spain). In brief, $200 \mu$ of the sample from each participant was put in appropriately labeled test tube containing 1.0 $\mathrm{ml}$ of working solution [containing one part of chromogen solution (ferozine $40 \mathrm{mmol} / \mathrm{L}$ and sodium acetate $400 \mathrm{mmol} / \mathrm{L}$ and four parts of buffer/reductant solution (Guanidine chloride $1.0 \mathrm{~mol} / \mathrm{L}$; hydroxylamine $0.6 \mathrm{~mol} / \mathrm{L}$; acetate

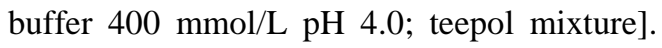
Similar procedure was used for the reagent blank and standard test tubes, except that the sample blank was prepared with addition of $1.0 \mathrm{ml}$ of the buffer/reductant solution. The reactions were incubated at room temperature for $5 \mathrm{~min}$, after which the absorbance of the sample blank was read at $560 \mathrm{~nm}$ against distilled water while the absorbance of the sample tests and standards were read at 560 $\mathrm{nm}$ against reagent blank. Subsequently, the concentration of serum iron was calculated.

\section{Statistical analysis}

The variables were expressed as mean $( \pm \mathrm{SD})$. The independent student t-test was used to assess significant mean differences. Significant level was considered at $<0.05$.

\section{RESULTS}

No significant difference was observed in PCV in Symptomatic and Asymptomatic HIV-malaria infected $(0.30 \pm 0.07,0.35 \pm 0.08)$ groups when compared to the malaria uninfected $\quad(0.31 \pm 0.04, \quad 0.34 \pm 0.04)$ counterparts $(\mathrm{P}>0.1, \mathrm{P}>0.1)$ respectively. Also no significant difference was observed between the HIV/AIDS malaria infected and uninfected subjects $(\mathrm{P}>0.1)$.

The mean serum iron concentration $(\mu \mathrm{g} / \mathrm{dl})$ in symptomatic and asymptomatic HIV-Malaria infected $\quad(97.30 \pm 56.40$, 
$81.20 \pm 36.70)$ groups were significantly reduced than in the corresponding HIVmalaria uninfected $(131.7 \pm 48.6,133.4 \pm$ 53.3) counterparts $(\mathrm{p}<0.01, \mathrm{p}<0.05)$. The malaria parasite density $(/ \mu \mathrm{l})$ for symptomatic HIV- malaria subjects was $604 \pm 440$. Similarly, the malaria parasite density for asymptomatic HIV-malaria infected subjects was $803 \pm 526$. In addition, the malaria parasite density for malaria infected HIV/AIDS subjects on ART was $690 \pm 480$. Furthermore, the malaria parasite density for malaria infected control subjects was $890 \pm$ 380. (Table 1)

The mean PCV (1/l) were significantly reduced in both Symptomatic and Asymptomatic HIV-malaria infected $(0.30 \pm$ $0.07,0.35 \pm 0.08)$ and uninfected $(0.31 \pm 0.04$, $0.34 \pm 0.04)$ subjects when compared to the corresponding control $(0.39 \pm 0.08,0.40 \pm$ $0.06)$ groups $(\mathrm{p}<0.01,<0.05,<0.05,<0.05)$. There was also significant reduction in mean PCV in HIV/AIDS malaria infected $(0.32 \pm$ $0.07)$ and uninfected $(0.32 \pm 0.04)$ subjects on ART when compared to control malariainfected $(0.39 \pm 0.08)$ and uninfected $(0.40 \pm$ $0.06)$ subjects $(\mathrm{p}<0.01)$ in each case.

The mean serum iron concentration in symptomatic and asymptomatic HIV-malaria infected groups was significantly lower than that of the control malaria infected $(158.7 \pm 69.70)$ group $(p<0.05)$. On the contrary, no significant difference was observed in mean serum iron of symptomatic HIV, asymptomatic HIV-malaria uninfected subjects when compared with the corresponding control $(165.9 \pm 88.9)$ subjects $(p>0.1)$ in each case.

Also the mean serum iron concentration in HIV/AIDS malaria infected and uninfected $(81.1 \pm 27.1,95.9 \pm 38.9)$ subjects on ART were significantly lower than the control counterparts $(158.7 \pm 96.2,165.9 \pm$ 88.9) $\mathrm{p}<0.05, \mathrm{p}<0.05)$ respectively.

However, there was no significant difference in malaria parasite densities amongst all the groups studied $(\mathrm{p}>0.1)$ (Table 2).

\section{DISCUSSION}

The present study shows that the packed cell volume (PCV) of malaria infected symptomatic HIV subjects on ART was not significantly different from the corresponding control. For the malaria uninfected symptomatic HIV subjects on ART, the PCV was significantly lower than the value observed in the corresponding control group. The PCV is synonymous with haemoglobin concentration $(\mathrm{Hb})$, which is greatly reduced in malaria infection due to excessive haemolysis of parasitized red blood cells (rbc). Anaemia (low PCV) is one of the commonest complications of malaria in children and pregnant women (Eliades et al., 2004; Murphy and Breman 2001; Cheesbrough Monica, 1998). HIV infection complicates the situation by making malaria attacks more frequent and severe (Whitwort et al., 2000; Laufer et al., 2006; Onyenekwe et al., 2008) and inducing loss of appetite which makes it difficult for the subjects to obtain the necessary nutrients required for erythropoiesis under normal conditions. The infiltration of the bone marrow by HIV virus (Moses et al., 1996), coupled with the suppressive effects of antiretroviral drugs will all act to reduce erythropoiesis and hence low PCV in malaria infected HIV subjects. The use of ART may improve the PCV by reducing viral load and encouraging erythropoiesis. It may also encourage nutritional stability by improving appetite. Furthermore, antiretroviral therapy (ART) improves immunity thereby reducing the incidence of clinical malaria hence $\mathrm{Hb}$ haemolysis is reduced. All these will lead to improved PCV and haemoglobin concentration. The study further showed that the mean serum concentration of iron was significantly reduced in malaria infected and uninfected symptomatic HIV group on ART when compared with the corresponding control group. The reduction was more marked in symptomatic HIV group than in 
Table 1: Packed Cell Volume (1/l), serum iron $(\mu \mathrm{g} / \mathrm{dl})$ and malaria parasite density $(/ \mu \mathrm{l})$ of malaria infected and uninfected symptomatic, asymptomatic HIV, HIV/AIDS subjects on ART and control subjects.

\begin{tabular}{lllc}
\hline Group & PCV $(\mathbf{l} / \mathbf{l})$ & Iron $(\boldsymbol{\mu g} / \mathbf{d l})$ & $\begin{array}{c}\text { Parasite } \\
\text { density } / \boldsymbol{\mu l}\end{array}$ \\
\hline Symptomatic HIV malaria infected $(\mathrm{n}=28)$ & $0.30 \pm 0.07$ & $97.30 \pm 56.40$ & $604 \pm 440$ \\
Symptomatic HIV malaria uninfected $(\mathrm{n}=25)$ & $0.31 \pm 0.04$ & $131.7 \pm 48.6$ & - \\
P value & $>0.1(\mathrm{~ns})$ & $<0.05$ & \\
Asymptomatic HIV malaria infected $(\mathrm{n}=35)$ & $0.35 \pm 0.08$ & $81.20 \pm 36.70$ & $803 \pm 526$ \\
Asymptomatic HIV malaria uninfected $(\mathrm{n}=32)$ & $0.35 \pm 0.08$ & $133.4 \pm 53.3$ & - \\
P value & $>0.1(\mathrm{~ns})$ & $<0.01$ & \\
HIV/AIDS malaria infected $(\mathrm{n}=28)$ & $0.32 \pm 0.07$ & $81.10 \pm 27.10$ & $690 \pm 480$ \\
HIV/AIDS malaria uninfected $(\mathrm{n}=19)$ & $0.32 \pm 0.04$ & $95.90 \pm 38.90$ & - \\
P value & $>0.1(\mathrm{~ns})$ & $>0.1(\mathrm{~ns})$ & \\
Control malaria infected $(\mathrm{n}=20)$ & $0.39 \pm 0.08$ & $158.7 \pm 96.20$ & $890 \pm 380$ \\
Control malaria uninfected $(\mathrm{n}=20)$ & $0.40 \pm 0.08$ & $165.90 \pm 88.90$ & - \\
P value & $>0.1(\mathrm{~ns})$ & $>0.1(\mathrm{~ns})$ & \\
\hline Tabulated values are Mean \pm SD. $\mathrm{ns}=$ not significant; PCV = Packed Cell Volume. & &
\end{tabular}

Table 2: Comparison of Packed Cell Volume (1/l), serum iron $(\mu \mathrm{g} / \mathrm{dl})$ and malaria parasite density $(/ \mu 1)$ in malaria infected and uninfected symptomatic, asymptomatic HIV, HIV/AIDS subjects on ART and control subjects.

\begin{tabular}{|c|c|c|c|}
\hline Group & PCV (1/l & Iron $(\mu \mathrm{g} / \mathrm{dl})$ & $\begin{array}{l}\text { Parasite } \\
\text { density } / \mu \mathrm{l}\end{array}$ \\
\hline Symptomatic HIV malaria infected & $0.30 \pm 0.07$ & $97.30 \pm 56.40$ & $604 \pm 440$ \\
\hline Control malaria infected & $0.39 \pm 0.08$ & $158.7 \pm 96.20$ & $890 \pm 380$ \\
\hline$P$ value & $<0.01$ & $<0.05$ & $>0.1$ \\
\hline Symptomatic HIV malaria uninfected & $0.31 \pm 0.04$ & $131.7 \pm 48.6$ & \\
\hline Control malaria uninfected & $0.40 \pm 0.08$ & $165.90 \pm 88.90$ & - \\
\hline$P$ value & $<0.05$ & $>0.1(\mathrm{~ns})$ & \\
\hline Asymptomatic HIV malaria infected & $0.35 \pm 0.08$ & $81.20 \pm 36.70$ & $803 \pm 526$ \\
\hline Control malaria infected & $0.39 \pm 0.08$ & $158.7 \pm 96.20$ & $890 \pm 380$ \\
\hline $\mathrm{P}$ value & $<0.05$ & $<0.05$ & $>0.1(\mathrm{~ns})$ \\
\hline Asymptomatic HIV malaria uninfected & $0.35 \pm 0.08$ & $133.4 \pm 53.3$ & \\
\hline Control malaria uninfected & $0.40 \pm 0.08$ & $165.90 \pm 88.90$ & - \\
\hline $\mathrm{P}$ value & $<0.05$ & $>0.1(\mathrm{~ns})$ & \\
\hline HIV/AIDS malaria infected & $0.32 \pm 0.07$ & $81.10 \pm 27.10$ & $690 \pm 480$ \\
\hline Control malaria infected & $0.39 \pm 0.08$ & $158.7 \pm 96.20$ & $890 \pm 380$ \\
\hline $\mathrm{P}$ value & $<0.01$ & $<0.05$ & $>0.1(\mathrm{~ns})$ \\
\hline HIV/AIDS malaria uninfected & $0.32 \pm 0.04$ & $95.90 \pm 38.90$ & \\
\hline Control malaria uninfected & $0.40 \pm 0.08$ & $165.90 \pm 88.90$ & - \\
\hline$P$ value & $<0.01$ & $<0.05$ & \\
\hline
\end{tabular}


those without malaria infection. This suggests a significant impact of malaria on serum iron concentration, which has been previously reported (Onyenekwe et al., 2008). The implication of this observation is that there is iron deficiency anaemia in malaria infected HIV subjects. The prevalence of iron deficiency anaemia in HIV infected children in Uganda was found to be $44.5 \%$ (Dana et al., 1999). The fact that serum iron was reduced in malaria infected HIV positive subjects suggests that serum iron could be the most sensitive indicator of possible impact of malaria infection in HIV infected subjects. Study reports elsewhere suggest the existence of significant relationship between iron status and HIV disease (Boelaert et al., 1996; Savarino et al., 1999). Serum iron has been associated with progression of HIV disease (Boelaert et al., 1996). It is believed that iron increased the oxidative stress, which enhances HIV replication in affected subjects (Jacobus et al., 19996; De Monye et al., 1999). Furthermore, iron loading and its subsequent deposition in tissues is said to be directly cytotoxic or harmful to immune effector cells including macrophages thereby increasing HIV-1 replication (Boelaert et al., 1996; Savarino et al., 1999). Other reports contradict any relationship between iron and HIV infection (Vanden Broek et al., 1998). Reports of iron deficiency anaemia in HIV positive pregnant women have been documented in developing countries (Asobayire et al., 2001). Onyenekwe et al., (2008) have reported a negative association between serum iron and PCV in Nigeria. Studies elsewhere have reported reduced haemoglobin concentrations, and transferrin, raised ferritin and transferrin saturation in malaria infected asymptomatic HIV subjects but similar serum iron concentration in malaria infected and uninfected control groups (Odunukwe et al., 2000). The findings in this study and the ones cited above could suggest possible depletion of iron stores in HIV infected subjects thereby making more iron available in transport. This is said to be detrimental to HIV infected subjects. Onyenekwe et al. (2008) believed that this process might be blocked and reversed by malaria infection especially in endemic areas thus favouring reduced iron in transport with consequent increase in storage.

In conclusion, the present study shows that malaria-HIV co-infection has a negative effect on affected subjects in the study area one of which is anaemia. Concerted efforts should therefore be made at the various levels of government to bring malaria and HIV infection under control so as to reduce the high mortality rates attributed to these two diseases.

\section{ACKNOWLEDGMENTS}

We sincerely wish to acknowledge the staff of the VCT unit, HIV laboratory unit of Nnamdi Azikiwe University Teaching Hospital Nnewi and the staff and management of Awka South Local Government Area, Anambra State, Nigeria.

\section{REFERENCES}

Boelaert JR, Weinberg GA, Weinberg ED. 1996. Altered iron metabolism in HIV infection. Mechanisms, possible consequences, and proposals for management: Infect. Agents Dis., 5: 3646.

Castaldo A, Tarallo L, Paloniba T, Albano F, Russo S, Zuin G, Buffardi F, Guarino A. 1996. Iron and intestinal malabsorption in HIV disease. J. Paediatri Gastroenterol Nutr., 22: 359-363.

Dana T, Christopher N, Francis M, Robert T, Per J, Brooks J, Richard D. 1999. Iron Deficiency Anaemia is Highly prevalent among human immunodeficiency virus infected and uninfected infants in Uganda. Community and International Nutrition.

De-Monye C, Karcher DS, Boelaert JR, Gordeuk VR. 1999. Bone marrow macrophage iron grade and survival of HIV -seropositive patients. AIDS, 13: 375-380.

Eliades MJ, Wolon A, Morgah K, Crawford SB, Dprlempp A, Sodahlon I, Hawley WA, Hightower AW, Kuile FO, Terionw 
DJ. 2004. Burden of malaria at community level in children less than 5 years of age in Togo PMID: 17038683 (Pub Med-in process).

Froebel K, Howard W, Schafer JR, Howie F, Whitworth J, Kaleebu P, Brown AL, Riley E. 2004. Activation by malaria antigens reders mononuclear cells susceptible to HIV infection and reactivates replication of endogenous HIV in cells from HIV-infected adults. Parasite Immunol., 26: 213-217.

Jacobus DP. 1996. Randomization to iron supplementation of patients with advanced human immunodeficiency virus disease: an inadvertent but controlled study with results important for patient care: J. Infect. Dis., 173: 1044-1045.

Kublin JG, Patnaik P, Jere CS, Miller WC, Hoffman IF, Chimbiya N, Pendame R, Taylor TE, Molyneux ME. 2005. Effect of Plasmodium falciparum malaria on concentration of HIV-1-RNA in the blood of adults in rural Malawi A prospective cohort study, Lancet, 365: 233-240.

Laufer MK, Van Oosterhout JJ, Thesing PC, Thumba F, Zijlstra EE, Graham SM, Taylor TE, Plowe CV. 2006. Impact of HIV-associated immunosuppression on malaria infection and disease in Malawi J. Infection Dis., 193: 872-878.

Menendez C, David SLQ, Elizeus K, Loisa A, John JA, Pedro LA. 2004. Effects of short-term iron supplementation on iron status in infants in malaria endemic areas. Am. J. Trop. Med. Hyg., 74(4): 434-440.

Mermin J, Lule JR, Ekwaru JP. 2006. Association between Malaria and CD4 cell Count Decline Among person with HIV. J. Acquir Immune Defic Syndr., 41: 129-130.

Moses AV, Williams S, Heneveld ML, Strussenberg J, Rarick M, Loveless M, Bagby G, Nelson JA. 1996. Human immunodeficiency virus infection of bone marrow endothelium reduces induction of stromal hematopoietic growth factors. Blood, 87(3): 919-925.
Murphy PM, Lane HC, Fauci AS. 1988. Impairment of neutrophil bacterial capacity in patients with AIDS. J. Infect Dis., 158: 627-630.

Odunukwe NN, Salako LA, Okany IM. 2000. Serum Ferritin and other Haematological measurement in apparently healthy adults with malaria parasitaemia in Lagos. Nigeria Trop. Med. \& International Health, 5(8): 582586.

Onyenekwe CC, Arinola OG, Salimonu LS, 2002. Detection of Plasmodium falciparium $\mathrm{IgG}$ and incidence of asymptomatic malaria in pregnant women in Nigeria. Indian J. Malarial, 39: 39-42.

Onyenekwe CC, Ukibe N, Meludu SC, Ifeanyi M, Ezeani M, Onochie A, Ofiaeli N, Aboh N, Ilika A. 2008. Possible biochemical impact of malaria infection in subjects with HIV co-infection in Anambra State. Nigeria J. Vector Borne Dis., 45: 151-156.

Okwa OO. 2004. Preliminary investigations on malaria in sickle cell patients among pregnant Women and infants in Lagos, Nigeria. Nig. J. Parsitol., 25: 81-85.

Patnaik P, Jere CS, Miller WC, Hoffman IF, Wirima J, Pendame R, Meshnick SR, Taylor TE, Molyneux ME, Kublin JG. 2005. Effects of HIV-1 serostatus, HIVRNA concentration, and $\mathrm{CD}^{4}$ cell count on the incidence of malaria infection in a cohort of adults in rural Malawi. J. Infect. Dis., 192: 984-991.

Te Kuile FO, Praise ME, Verhoeff FH, Udhayakumar V, Newman RD, Van Ejk AM, Rogerson SJ, Steketee RW. 2004. The burden of co-infection with human immunodeficiency virus type 1 and malaria in pregnant women in subSaharan African. Am. J. Trop. Med. Hyg., 71: 41-54.

Tkachuk AN, Moormann AM, Poore JA, Richford RA, Chensue SW, Mwapasa V, Meshnick SR. 2001. Malaria enhances expression of $\mathrm{CC}$ chemokine receptor 5 on placental macrophages. J. Infect Dis., 183: 967-972. 
UNAIDS (Joint United Nations Programme on HIV/AIDS). 2004. AIDS Epidemic update: December 2004. UNAIDS, Geneva, 200.

Van den Broek NR, Letsky EA, White SA, Shenkin A. 1998. Iron Status in pregnant women: Which measurements are valid? Br. J. Haematol., 103: 817-824.

Whitworth J, Morgan D, Quigley M, Smith A, Mayanja B, Eotu H, Omoding N, Okongo M, Malamba S, Ojwiya A. 2000. Effect of HIV-1 and increasing immunosuppression on malaria parasitaemia and clinical episodes in adults in rural Uganda: a cohort study, Lancet, 356: 1051-1056.
Whitworth JA, Hewitt KA. 2005. Effect of malaria on HIV-1\Progression and transmission. Lancet, 365: 196-197.

World Health Organization. 2006. The roll back malaria Partnership Available at: ptty://rbm.who.int/publications. html accessed May 5, 2006.

Xiao L, Owen SM, Rudolph DL, Lal RB, Lal AA. 1998. Plasmodium falciparum antigen-induced human immunodeficiency virus type 1 replication is mediated through induction of tumor necrosis factor-alpha. J. Infect Dis., 177: 437-445. 